\title{
Heat flow asymmetry on the mid-oceanic ridges of Northern and Southern Earth hemispheres
}

\author{
M.D. Khutorskoy*, E.A. Teveleva \\ Geological Institute of the Russian Academy of Sciences, Moscow, Russian Federation
}

\begin{abstract}
A statistical analysis of heat flow (HF) distribution along nine geotravers crossing the midoceanic ridges in the Atlantic, Pacific and Indian oceans is carried out. A significant asymmetry in HF distribution is established - its mean values differ on opposite sides of the ridges axis. In the Earth southern hemisphere geotraverses, their western flank has a higher HF mean, and in the northern hemisphere geotraverses there is the eastern flank. Various tectonic factors that lead to such a distribution are taken into account, but the universal cause of this regularity is suggested to be the effect of the Coriolis force, which deflects the ascending magma flow in divergent zones, when the planet rotates, respectively, to the west - in the southern and to the east - in the northern hemispheres.
\end{abstract}

Keywords: heat flow, geotraverses, statistic, asymmetry, mid-oceanic ridge, Coriolis force

Recommended citation: Khutorskoy M.D., Teveleva E.A. (2018). Heat flow asymmetry on the midoceanic ridges of Northern and Southern Earth hemispheres. Georesursy = Georesources, 20(2), pp. 122-132. DOI: https://doi.org/10.18599/grs.2018.2.122-132

Detailed heat flow studies within the slopes of the mid-oceanic ridges and adjacent abyssal basins have shown that its distribution is not symmetric everywhere relative to the ridge axis in the same-type zones, but is subject to a complex redistribution mechanism that depends on many geological causes associated with tectonics and features of the structure of the lithosphere of these zones.

The presence of the geothermal asymmetry of the mid-ocean ridges (MOR) slopes, adjacent abyssal basins and passive parts of the transform faults in the Atlantic, Indian and Pacific Oceans was justified and confirmed on the basis of statistical processing of data from the global heat flow database along the geotraverses, Crossing MOR and covering the above structural elements of the oceanic crust (Podgornykh, Khutorskoy, 1998; Podgornykh, Khutorskoy, 1999; Khutorskoy, Teveleva, 2016; Khutorskoy, Polyak, 2017; Khutorskoy, et al., 2017). It is important to note that the MOR asymmetry is observed not only in the thermal field, but also in other geophysical fields: magnetic (Glebovsky et al., 1986) and gravity (Budanov et al., 1997), and also in the crust structure (Naryshkin, Pogrebitsky, 1986, Pushcharovsky et al., 1995).

The nature of this phenomenon was repeatedly discussed, and various geological and geophysical

\footnotetext{
"Corresponding author: Mikhail D. Khutorskoy

E-mail:mkhutorskoy@ginras.ru

(C) 2018 The Authors. Published by Georesursy LLC

This is an open access article under the CC BY 4.0 license

(https://creativecommons.org/licenses/by/4.0/)
}

models were proposed to explain the existing asymmetry. Some researchers note the existence of different oceanic plates spreading rates on different sides of the ridges axis (Naryshkin, Pogrebitsky, 1986; Pushcharovsky et al., 1995; Schrader, 2001), others believe that the geodynamic processes in the adjacent plates differ, and on one of them the compression regime, which replaced the initial tension situation, creates overthrust structures characteristic for compression (Budanov et al., 1997; Pushcharovsky et al., 1995).

We previously proposed to consider the influence of the Coriolis force (Khutorskoy, Teveleva, 2018), which acts on any mass, moves along the radius of the rotating Earth and diverts this mass from the orthogonal trajectory, respectively, to the west in the southern hemisphere and to the east - in the northern hemisphere. An upward flow of magma in the divergent zones of the middle ridges can be considered as such a "mass". The deviation of this flow from a trajectory orthogonal to the planet's surface determines the observed geothermal asymmetry.

The purpose of this paper is a comparative analysis of the heat flow distribution along geotraverse crossing MOR in the southern and northern hemispheres of the planet. Naturally, we consider those MOR intersections, which are most representative of heat flow measurements. The compilation of measured heat flow values is reflected in global databases (Jessop et al., 1976; Pollack et al., 1992; Podgornykh, Khutorskoy, 1997; Hasterok, 2010).

To establish the fact of geothermal asymmetry 
on the MOR slopes, we compared heat flow data for the same type of elements along the long profiles (geotraverses) crossing the ridges in the World Ocean: the Mid-Atlantic ridge, the East Pacific Rise and the West Indian Ridge (Fig. 1). Statistical sampling for each of these geotraverses is quite representative (Table 1) for comparative analysis.

The proof of the possible geothermal asymmetry of structural morphological elements along geotraverses is based on a statistical comparison of empirical data related to different its parts, in our case, to its western and eastern strike.

To verify of the statistically significant difference in the mean heat flow values, the parametric Cramer-Welch criterion $(\mathrm{T})$ was used in the samples, the value of which is found from the formula (Gmurman, 2015):

$$
T=\frac{\sqrt{m n} \cdot(\bar{x}-\bar{y})}{\sqrt{n s_{x}^{2}+m s_{y}^{2}}},
$$

where $\bar{x}, s_{x}^{2}, n$ and $\bar{y}, s_{y}^{2}, m$, respectively, sample means, variances, and the amount of data from two comparative samples.

If $T<\varphi\left(1-\frac{\alpha}{2}\right)$, where $\varphi\left(1-\frac{\alpha}{2}\right)$ is the inverse of the normal distribution function from the significance level $\alpha$, where $\alpha=1-\mathrm{P}$, P is the confidence probability, then the hypothesis of homogeneity of the mean heat flow values, i.e. the existence of asymmetry is not confirmed.

\begin{tabular}{|l|c|c|c|c|}
\hline No. geotraverse & \multicolumn{2}{|c|}{$\begin{array}{c}\text { No. 1 } \\
\text { Angola-Brazil }\end{array}$} & \multicolumn{2}{|c|}{$\begin{array}{c}\text { No. 2 } \\
-31^{\circ} \text { s.1. }\end{array}$} \\
\hline west/east & west & east & west & east \\
\hline $\begin{array}{l}\text { Average value } \\
\text { of heat flow }\end{array}$ & 62 & 39 & 91 & 61 \\
\hline Standard deviation & 25 & 21 & 94 & 62 \\
\hline $\begin{array}{l}\text { Number of } \\
\text { measurements }\end{array}$ & 16 & 18 & 6 & 27 \\
\hline $\begin{array}{l}\text { Value of Cramer-Welch } \\
\text { criterion }\end{array}$ & \multicolumn{2}{|c|}{3} & \multicolumn{2}{|c|}{0,99} \\
\hline Confidence probability & \multicolumn{2}{|c|}{$99 \%$} & \multicolumn{2}{|c|}{$70 \%$} \\
\hline
\end{tabular}

Table 1. Statistical characteristics of geotraverse in the southern hemisphere of the Atlantic Ocean

If $T \geq \varphi\left(1-\frac{\alpha}{2}\right)$, then the hypothesis is accepted that the

average values for the considered feature are nonuniform, and the asymmetry is confirmed. With a significance level $\alpha=0.05$ (at $\mathrm{P}=95 \%$ ), the critical value of the Cramer-Welch criterion is $\mathrm{T}=1.96$. Therefore, if the value of the criterion does not exceed this value, then it is necessary to accept the hypothesis of homogeneity of the sample data by the mean value. If the value of the criterion is greater than or equal to the critical value, then the samples by the mean value are recognized as different.

\section{Southern hemisphere of the Earth}

In the southern hemisphere, we analyzed the heay flow distribution along five geotraverses: 1) Angola-Brazil geotraverse $\left.\left(12{ }^{\circ} \mathrm{S}\right), 2\right)$ geotraverse along $31^{\circ} \mathrm{S}-$ in the

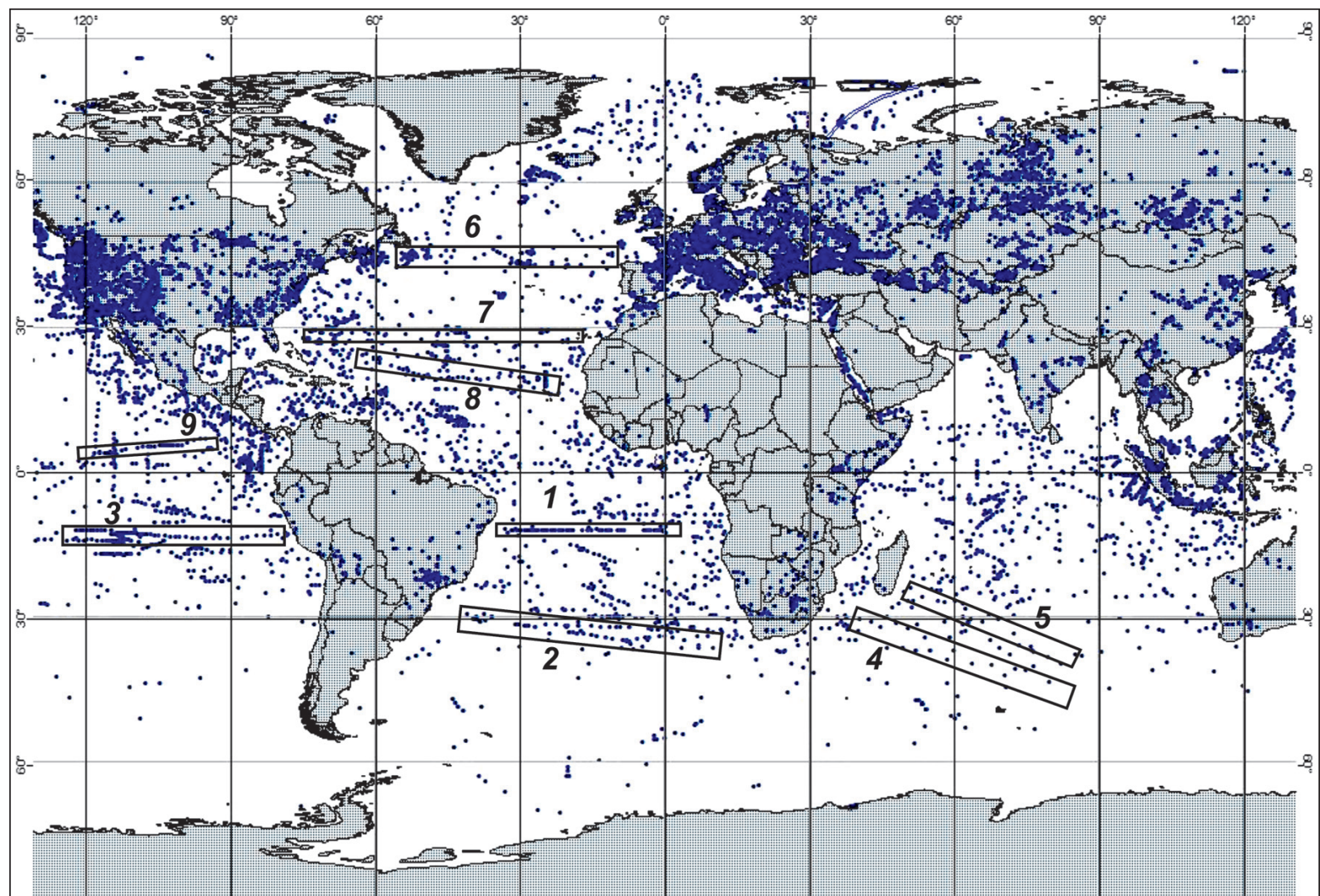

Fig. 1. The scheme of the location of the measurement points of the heat flow and the investigated geotraverses in the World Ocean (see the text for the numbers) 
Atlantic Ocean; 3) geotraverse $15{ }^{\circ} \mathrm{S}$ - in the Pacific Ocean, as well as geotraverse in the Indian Ocean: 4) the southern part of the Crozet-Mozambique Basin and 5) the northern part of the Crozet-Madagascar (Fig. 1).

\section{Atlantic Ocean}

Most of the geothermal data for the Angolo-Brazilian geotraverse (No.1) was obtained during many years of expeditionary geological and geophysical research by VNIIOceangeology (Podgornykh, Khutorskoy, 1998; Popova et al., 1984; Pogrebitsky et al., 1990; Mashchenkov, Pogrebitskii, 1995).

Within the Angola-Brazil geotraverse, detailed heat flow measurements, gravitational and magnetic fields, the bottom relief, and a large volume of seismic surveys were carried out.

The bottom morphostructure along the geotraverse conform to the traditional transoceanic structures scheme (Naryshkin, Pogrebitsky, 1986). In the central part of the geotraverse there is a mid-Atlantic uplift, on both sides of which abyssal plates lie (the Angolan and Brazilian basins) and the marginal-continental flexures (African and South American continental slopes with foothills) interfaced with plates (Fig. 2). The listed first-order structures are complicated by a system of subordinate and superimposed morphostructures: mosaic-cellular and linear-ridge uplifts, plateaus, troughs, volcanic buildings of central type are distinguished. Despite the smooth interface of structures in general, longitudinal zones relative to the middle ridge of the zone are contacted by faults. Based on the landscape characteristics (size, amplitude, orientation), the asymmetry of the wings of the median uplift is noted: in the formation of the basalt bed, the tectonic -magmatic activity was most intensively manifested in the western "Brazilian" wing (Pogrebitsky et al., 1990).

The structure of the magnetic field of the western and eastern flanks of the uplift is also asymmetric. The anomalies of the western flank are characterized by a relatively high intensity (up to $150 \mathrm{nT}$ ) and a more consistent linearity. They are well identified up to the 33rd anomaly inclusive. Anomalies of the eastern flank are characterized by smoothed (up to $100 \mathrm{nT}$ ) fragmentarily linear field with alternating signs, and the correlation is quite arbitrary here (Mashchenkov, Pogrebitskii, 1995). Asymmetry in the structure of the anomalous magnetic field of the western and eastern flanks of the middle elevation is also established on the geomagnetic cross-section: the surface of the lower edges of magnetized bodies on the western flank does not deeper than $12 \mathrm{~km}$, and in the east reaches $20 \mathrm{~km}$ from the ocean surface.

According to the data of CDP, there are structural seams buried beneath the sedimentary cover. On the seismic section, they are expressed in the form of a powerful reflector that passes through the entire crust and displaces the Moho surface. Although these seams are not expressed either in the bottom relief or in the gravitational field, in the structural plan they also give grounds for assuming the asymmetry of the

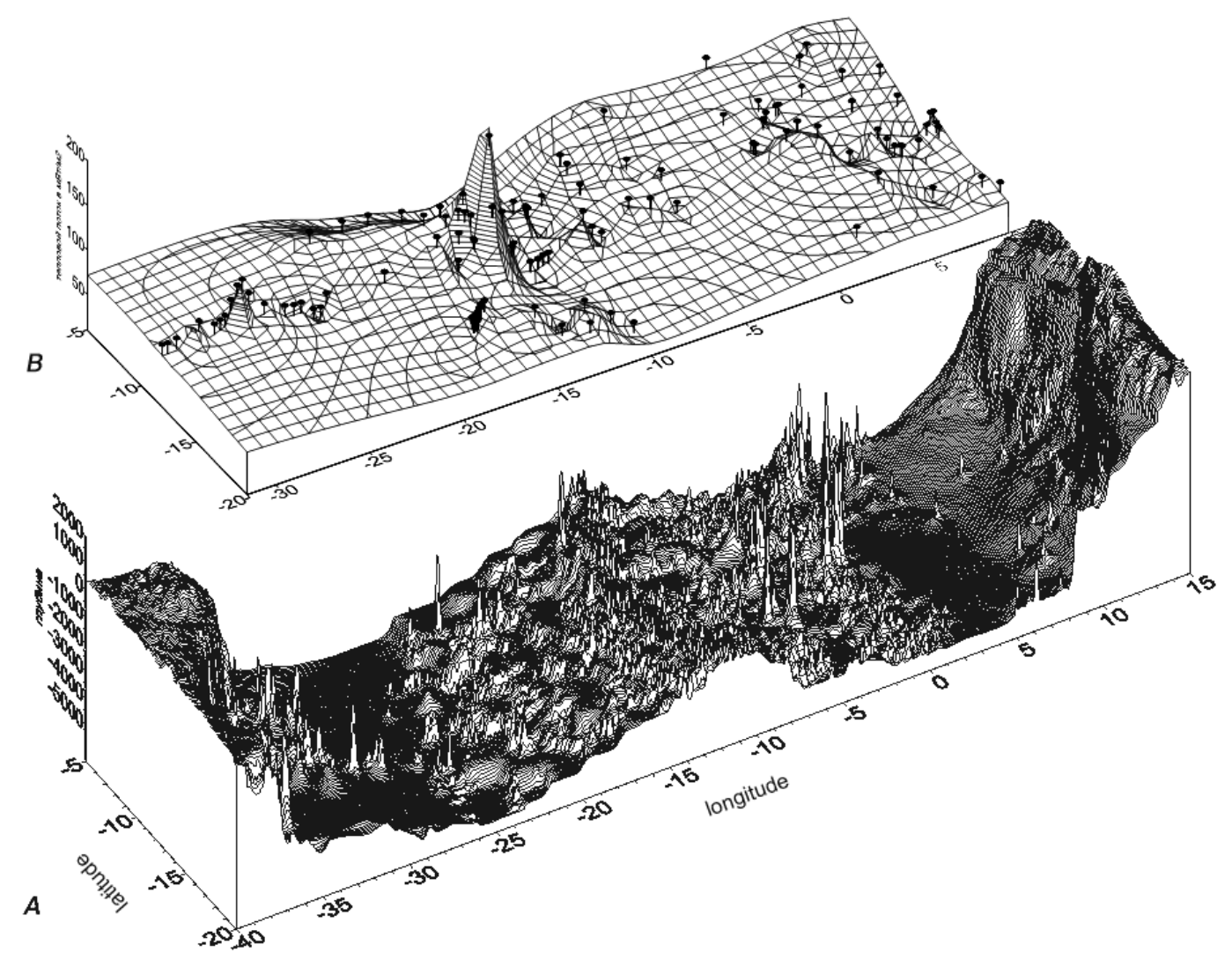

Fig. 2. The relief of the bottom (A) and the heat flow (B) along the Angola-Brazil geotraverse 
underlying tectonic processes. On the Angolan seam, the oceanic lithosphere is advancing on the surface of the paleocontinental slope toward the continent, and on the Brazilian slope listric slipping off is observed.

The observed asymmetry in the deep structure of the slopes and abyssal basins along the geotraverse, as well as in the magnetic field, is naturally related to the difference in the energy of the geodynamic processes, which can be judged from the analysis of geothermal data. They showed, at statistical processing and calculation of the Cramer-Whelch criterion, a significant difference in heat flow on different sides of Mid-Atlantic Ridge. Thus, the average heat flow to the west of the Mid-Atlantic Ridge is $62 \mathrm{~mW} / \mathrm{m}^{2}$, and to the east $39 \mathrm{~mW} / \mathrm{m}^{2}$ (Table 1 ).

Discussing the reasons for the geothermal asymmetry of the ridge, we can agree in the first approximation with the authors of the report (Pogrebitsky et al., 1990, p. 21), who explain it "... by the absence of a single mechanism for the formation of the oceanic lithosphere", but the result obtained by us suggest the presence of additional deep thermal sources, which caused an increase in heat flow on the western flank of the ridge in the geotraverse zone.

We can assume either the presence of different lithosphere thicknesses from the western and eastern sides of the ridge (in this case, differences in the background heat flow values will remain in the stationary geothermal field), or the action of non-stationary and later geodynamic processes that altered the thermal structure of the already formed oceanic lithosphere.

The first of our assumptions does not agree with the independent geophysical results obtained in the study of geotraverse, and also with estimates of the lithosphere thicknesses from the bottom bathymetry data (Mashchenkov et al., 1998). The second assumption is more real, because structural heterogeneity and the presence of superimposed tectonic processes in the formed lithosphere is confirmed by magnetometry and seismic profiling data.

Geotraverse along $31^{\circ} \mathrm{S}$ stretches from the Cape basin in the east to the Plateau Rio-Grande in the west of the Atlantic Ocean. In the geotraverse strip ${ }^{1}$, there are 6 measurements to the west of the Mid-Atlantic Ridge and 27 measurements to the east. Applying the same method of data comparison, we calculated that the average heat flow west of Mid-Atlantic Ridge is $91 \mathrm{~mW} / \mathrm{m}^{2}$, and to the east $61 \mathrm{~mW} / \mathrm{m}^{2}$, i.e. came to a similar result: the western flank of the Mid-Atlantic Ridge on the geotraverses of the southern hemisphere in the Atlantic has a higher heat flow (Table 1).

As was announced above, we will discuss more general and universal models for explaining the observed asymmetry of heat flow after characterizing all geotraverses.

The sampling of the heat flow data included all measurements located in a stripe $\pm 2^{\circ}$ from the geotraverse axis.

\section{Pacific Ocean}

In the southern hemisphere of the Pacific Ocean, we examined one geotraverse crossing the East Pacific Rise at $15{ }^{\circ} \mathrm{S}$. The East Pacific Rise represents one of the main links of the global chain of mid-oceanic ridges. In the southeastern Pacific it serves as a boundary between the Pacific plate in the west and the plates of the Antarctic, Chilean, Nazca and Cocos in the east. Morphologically, the uplift is expressed in the form of a wide (1000-1200 km) swell with gentle slopes dissected into large and small blocks, among which submarine volcanic mountains or volcanic arrays are elevated. Parallel to the main axis of the East Pacific Rise, sometimes there are clay-volcanic uplifts of relatively small extent. The crest of the East Pacific Rise is located at a depth of $2-3 \mathrm{~km}$, and only a few individual volcanoes rise to less than $2 \mathrm{~km}$. The highest point of the ridge in this part of the ocean is Easter Island, located in the zone of its connection with the latitude-volcanic Sala y Gomez ridge.

The peculiarity of the East Pacific Rise, which distinguishes it from other middle ridges, is the absence of a longitudinal rift valley and its ridge framing, which is explained by the high rate of spreading (up to $16 \mathrm{~cm} /$ year), at which abundant masses of magmatic material arriving at the surface completely fill rift valley (Naryshkin, Pogrebitsky, 1986; Menard, 1966).

Sedimentary layer on the rise is quite thin, and in a number of places and generally absent. The second layer, represented mainly by basalts, has a thickness of $1 \mathrm{~km}$, and the "basalt layer", which, judging by the results of dredging on the Heizen fault in the 24th cruise of the Academik Kurchatov R/V, consists of amphibolite shales, $6-3.7 \mathrm{~km}$, which is almost $2 \mathrm{~km}$ less than the thickness of this layer outside the East Pacific Rise. G. Menard in his works called the East Pacific Rise as a meganticlinal uplift of the oceanic crust, in which the layers gradually become thinner as they approach the crust (Gainanov, 1980).

Throughout the course of the East Pacific Rise, it is dissected by numerous transform faults, over which its blocks are sometimes displaced over considerable distances. For example, the displacement of the East Pacific Rise axis in the Heisen and Tharp faults of the Eltanin transform system between 53 and $57^{\circ} \mathrm{S}$ reaches $15^{\circ}$ in longitude, i.e. more than $1500 \mathrm{~km}$. The nature of the displacements varies along the strike of the East Pacific Rise: to the south of the parallel $40^{\circ} \mathrm{S}$ the righthand displacements predominate, between $40^{\circ}$ and 20 ${ }^{\circ} \mathrm{S}$ - left-sided, and northern of $20^{\circ} \mathrm{S}$, right up to the junction with the latitudinal Galapagos uplift, again right-sided ones predominate.

Many researchers also note similar features in the geophysical fields of the southern part of the mid-Atlantic ridge and the East Pacific Rise in the southeastern Pacific 
(Kuo, Forsyth, 1988). This similarity is expressed in identical anomalies of the total geomagnetic field vector and gravitational anomalies in the free air reduction.

American and Canadian scientists obtained the main volume of geothermal measurements in this part of the Pacific Ocean. Nevertheless, about 50 heat flow measurements were carried out by Russian scientists, including the authors of this work, during the 14th cruise of the "Dmitry Mendeleyev" $\mathrm{R} / \mathrm{V}$ and the 24th cruise of the "Akademik Kurchatov" R/V (Popova et al., 1984).

Geotraverse area $15{ }^{\circ} \mathrm{S}$ is characterized by the highest geothermal knowledge from all considered objects. A total of 7260 heat flow measurements were analyzed here, of which 3740 are located western of the East Pacific Rise axis, and 3520 are to the east. The calculation of the statistical difference in the samples showed that at this intersection of the East Pacific Rise there is a significant asymmetry of the heat flow: its mean value to west of the ridge is $88 \mathrm{~mW} / \mathrm{m}^{2}$, and to the east $72 \mathrm{~mW} / \mathrm{m}^{2}$ (Table 2).

\section{Indian Ocean}

In this paper, we analyzed heat flow distribution on the flanks of the South-West Indian Ridge (Fig. 1). It is morphologically divided into the West-Indian ridge and the African-Antarctic ridge, the connection of which occurs in the zone of the Prince Edward transform fault at $37^{\circ} \mathrm{E}$ (Fig. 3). The ridges are characterized by an intensely subdivided relief with a height difference of up to $4 \mathrm{~km}$. They are intersected by numerous transform faults, displacing the modern spreading axis sometimes for tens of miles (Schrader, 2001).

South-West Indian Ridge refers to slowly spreading ridges (Hosford, 2001). The spreading rate here, on the average, does not exceed $14 \mathrm{~km} /$ million years $(1.4 \mathrm{~cm} / \text { year })^{2}$, and the accretion of the crust on both sides of the ridge axis is sharply asymmetric. So, on the "Antarctic" side it is $8.5 \mathrm{~km} /$ million years, and on the "African" side it is $5.5 \mathrm{~km} /$ million years (Cannat et al., 1999). Along the strike of South-West Indian Ridge,

\begin{tabular}{|l|c|c|}
\hline No. geotraverse & \multicolumn{2}{|c|}{$\begin{array}{c}\text { No. 3 } \\
-15^{\circ} \text { s.l. }\end{array}$} \\
\hline west/east & west & east \\
\hline $\begin{array}{l}\text { Average value } \\
\text { of heat flow }\end{array}$ & 88 & 72 \\
\hline Standard deviation & 61 & 59 \\
\hline Number of measurements & 3745 & 3520 \\
\hline $\begin{array}{l}\text { Value of Cramer-Welch } \\
\text { criterion }\end{array}$ & \multicolumn{2}{|c|}{2,84} \\
\hline Confidence probability & \multicolumn{2}{|c|}{$99 \%$} \\
\hline
\end{tabular}

Table 2. Statistical characteristics of geotraverse in the southern hemisphere of the Pacific Ocean

${ }^{2}$ For comparison, the average spreading rate is $2.5 \mathrm{~cm} /$ year on the Mid-Atlantic ridge.

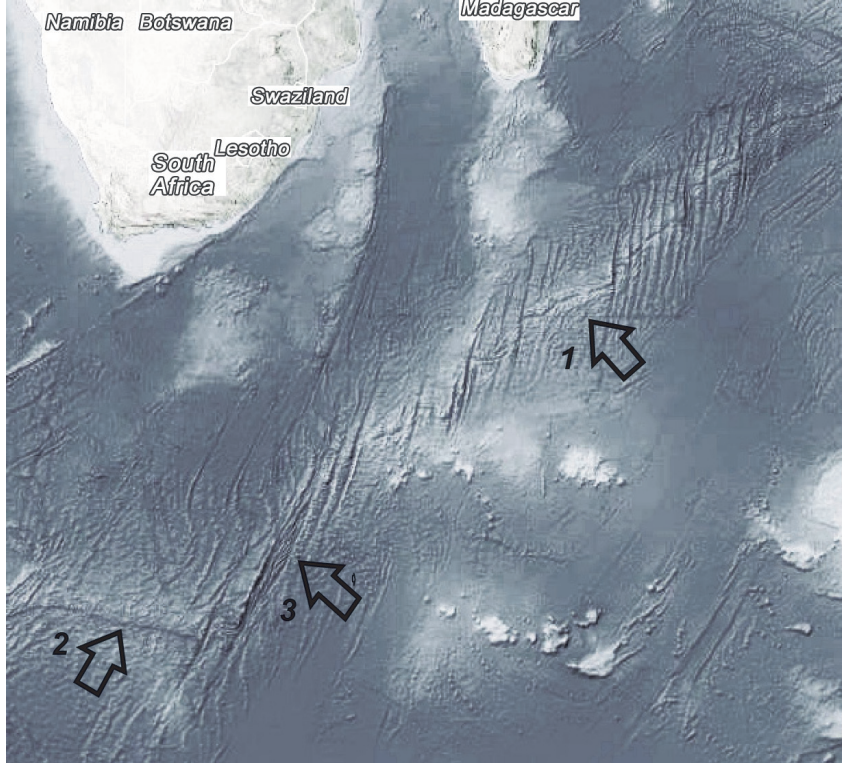

Fig. 3. Morphological scheme of the South-West Indian Ridge. The arrows show: 1 - West Indian ridge; 2 - the African-Antarctic ridge; 3 - the transform fault of Prince Edward.

structural asymmetry is also observed. The parts of the ridge lying west of the Andrew Bayne transform fault $\left(30^{\circ} \mathrm{E}\right)$ and east of the Malville transform fault $\left(61^{\circ} \mathrm{E}\right)$ are characterized by an abnormally deep axial valley, oblique spreading, a small central magnetic anomaly and unstable morphological manifestation at the bottom of transform faults passive parts (Patriat et al., 1997; Cannat et al., 1999).

Such properties of the peripheral parts of SouthWest Indian Ridge allow us to assume that they have a relatively "cold" mantle, a strong and thick lithosphere and limited magma reserves. On the contrary, the central part of South-West Indian Ridge, between 30 and $61^{\circ} \mathrm{E}$, is characterized by superficially manifested transformations in the relief, orthogonal spreading and a pronounced central magnetic anomaly (Patriat et al., 1997). Within this part of South-West Indian Ridge, between the transform faults of Atlantis II $\left(56^{\circ} 45^{\prime} \mathrm{E}\right)$ and Navar $\left(58^{\circ} 40^{\prime} \mathrm{E}\right)$, lies a segment which, judging by the spreading rate, can be compared with most segments Mid-Atlantic ridge.

Thus, South-West Indian Ridge is characterized by structural and morphological asymmetry along and across its strike.

In the southwestern part of the ocean, since the late 60 s of the 20th century, expeditions to American, French and Japanese research vessels have been carried out repeatedly, including heat flow measurements (Anderson et al., 1977; Anderson et al., 1979, Courtney, Recq, 1986, Hyndman et al., 1987). The compilation of the measured heat flow values is reflected in global databases (Jessop et al., 1976; Pollack et al., 1992; Podgornykh, Khutorskoy, 1997; Hasterok, 2010). Figure 4 shows all known points of measurement in this part of the Indian Ocean. 
To establish the fact of geothermal asymmetry on the flanks of West Indian Ridge, we compared the samples of heat flow data along two long geotraverses crossing the ridge (Fig. 4). Statistical sampling for each of these geotraverses is quite representative (Table 3 ) for comparative analysis.

Thus, in the southwestern part of the Indian Ocean, we note the presence not only of a structural but also a geothermal asymmetry of the West Indian Ridge relative to its axis. The western slope and the adjacent abyssal basin are characterized by a higher heat flow than the eastern part of the West Indian Ridge in the strip of both geotraverses.

Summing up the statistical analysis of the asymmetry of the MOR of the southern hemisphere, we note that for all crossings of ridges in the three oceans of the Earth, the western flank has a higher heat flow than the eastern one.

\section{Northern hemisphere of the Earth}

In the northern hemisphere four geotraverses were considered: 6) geotraverse $45^{\circ} \mathrm{N}, 7$ ) Canary-Bahamian geotraverse $\left.\left(28^{\circ} \mathrm{N}\right), 8\right)$ geotraverse $19^{\circ} \mathrm{N},-$ in the Atlantic and 9) geotravers $10^{\circ} \mathrm{N}$ in the Pacific Ocean.

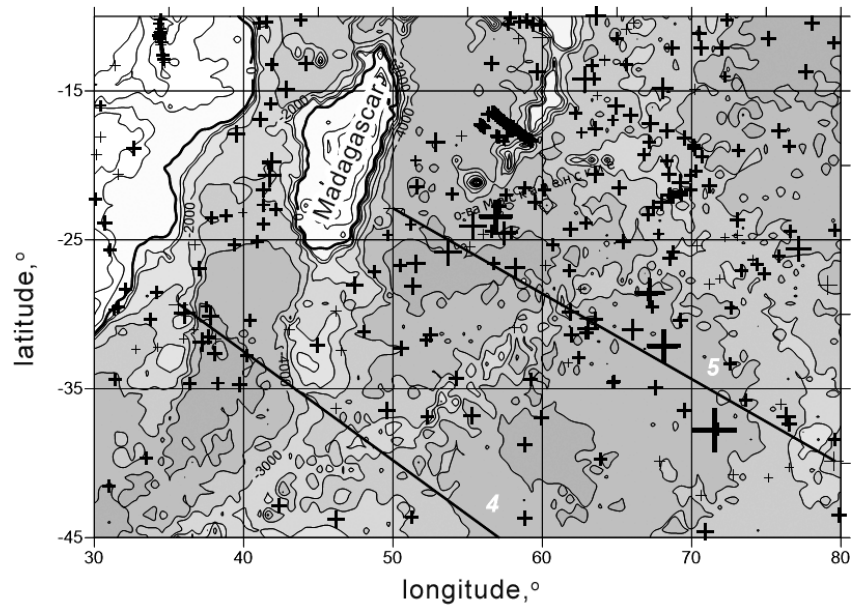

Fig. 4. Bathymetric map of the southwestern part of the Indian Ocean (cross-section of isobaths - $1000 \mathrm{~m}$ ) and location of points of heat flow measurement (crosses). The size of crosses is proportional to the amount of heat flow. 4-5 - geotraverse, along which statistical processing of geothermal data was carried out.

\begin{tabular}{|l|c|c|c|c|}
\hline No. geotraverse & \multicolumn{2}{|c|}{ No. 5 } & \multicolumn{2}{c|}{ No. 4 } \\
\hline $\begin{array}{l}\text { West or East of } \\
\text { West Indian Ridge axis }\end{array}$ & W. & E. & W. & E. \\
\hline Average value of heat flow & 76 & 48 & 124 & 77 \\
\hline Standard deviation & 59 & 30 & 79 & 40 \\
\hline Number of measurements & 65 & 28 & 12 & 48 \\
\hline $\begin{array}{l}\text { Value of Cramer-Welch } \\
\text { criterion }\end{array}$ & \multicolumn{2}{|c|}{2,38} & \multicolumn{2}{|c|}{2,9} \\
\hline Confidence probability & \multicolumn{2}{|c|}{$99 \%$} & \multicolumn{2}{c|}{$99 \%$} \\
\hline
\end{tabular}

Table 3. Statistical characteristics for the values of the heat flow $\left(\mathrm{mW} / \mathrm{m}^{2}\right)$ according to geotraverses No. 5 and No. 4

\section{Atlantic Ocean}

Geotraverse $45^{\circ} \mathrm{N}$ extends from the Bay of Biscay in the east to the Newfoundland depression in the west, crossing the Mid-Atlantic Ridge by $28^{\circ} \mathrm{W}$. The area has been thoroughly studied by all geological and geophysical methods. Suffice it to say that only measurements of the heat flow here are more than 250 (Fig. 5). The range of the heat flow is very wide. The minimum value is $25 \mathrm{~mW} / \mathrm{m}^{2}$, and the maximum value is $180 \mathrm{~mW} / \mathrm{m}^{2}$. Note that the Mid-Atlantic Ridge in this region is not characterized by the most extreme values, which is usually associated with a decrease in the conduction heat flow due to heat and mass transfer in the rift valley of the ridge.

The maximum heat flow values refer to the eastern slope of the Mid-Atlantic Ridge in the region of the 8-10th magnetic anomalies. Further to the east, in the Bay of Biscay, heat flow decreases somewhat, but, nevertheless, remains elevated compared to the Newfoundland depression. A comparison of heat flow samples to the west and east of the Mid-Atlantic Ridge axis showed that the sample in the east has a statistically significant excess of the average values above the sample in the west (Table 4).

The position of the Canary-Bahamian geotraverse $\left(23-29^{\circ} \mathrm{N}\right)$ is chosen so that it intersects only one divergent plate boundary (Mid-Atlantic Ridge) (Fig. 6), which functioned throughout the history of the Atlantic expansion. The geotraverse strip covers the region most representative for the processes of accretion and evolution of the oceanic crust in a slow spreading environment, as located between the most distant from each other Atlantic transform faults - Kane and Atlantis (Mashchenkov, Pogrebitskii, 1995).

According to the seismic results, two earth's crust types are distinguished in the geotraverse area, with a certain wave field structure and velocity characteristics, the normal and anomalous crust. Normal crust is characterized by the presence of three seismic complexes: the first seismic complex, which, in accordance with the features of the wave field, is compared with the pillowlavas and basalt flows in the ophiolite sections; the second - (acoustically transparent horizon) is interpreted

\begin{tabular}{|l|c|c|}
\hline No. geotraverse & \multicolumn{2}{|c|}{$\begin{array}{c}\text { No. } 6 \\
\left(45^{\circ} \text {. } 1.1 .\right)\end{array}$} \\
\hline west/east & west & east \\
\hline Average value of heat flow & 69 & 84 \\
\hline Standard deviation & 57 & 43 \\
\hline Number of measurements & 95 & 200 \\
\hline $\begin{array}{l}\text { Value of Cramer-Welch } \\
\text { criterion }\end{array}$ & \multicolumn{2}{|c|}{2,6} \\
\hline Confidence probability & \multicolumn{2}{|c|}{$99 \%$} \\
\hline
\end{tabular}

Table 4. Statistical characteristics for the values of the heat flow $\left(\mathrm{mW} / \mathrm{m}^{2}\right)$ according to geotraverses No. 6 


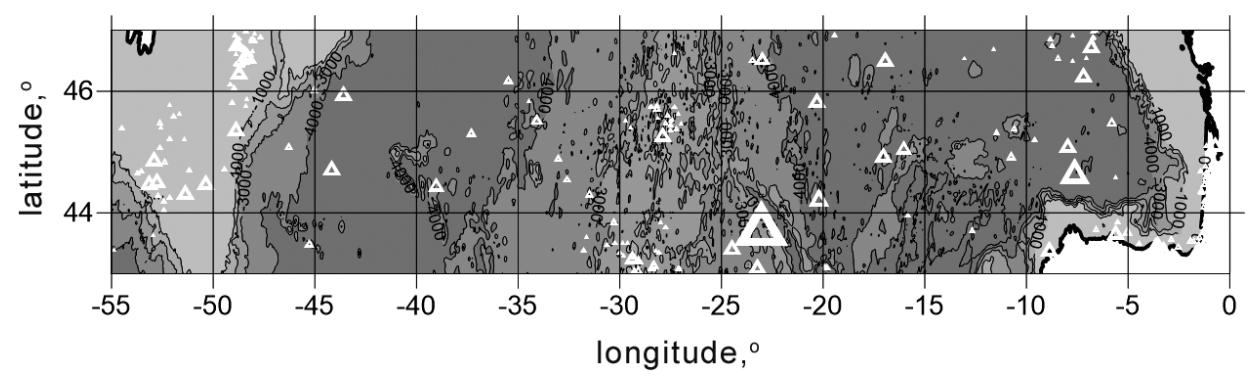

Fig. 5. The relief of the bottom and the points of measurement of the heat flow (triangles) in the region of geotraverse $45^{\circ} \mathrm{N}$. The size of the triangles is proportional to the value of the heat flow

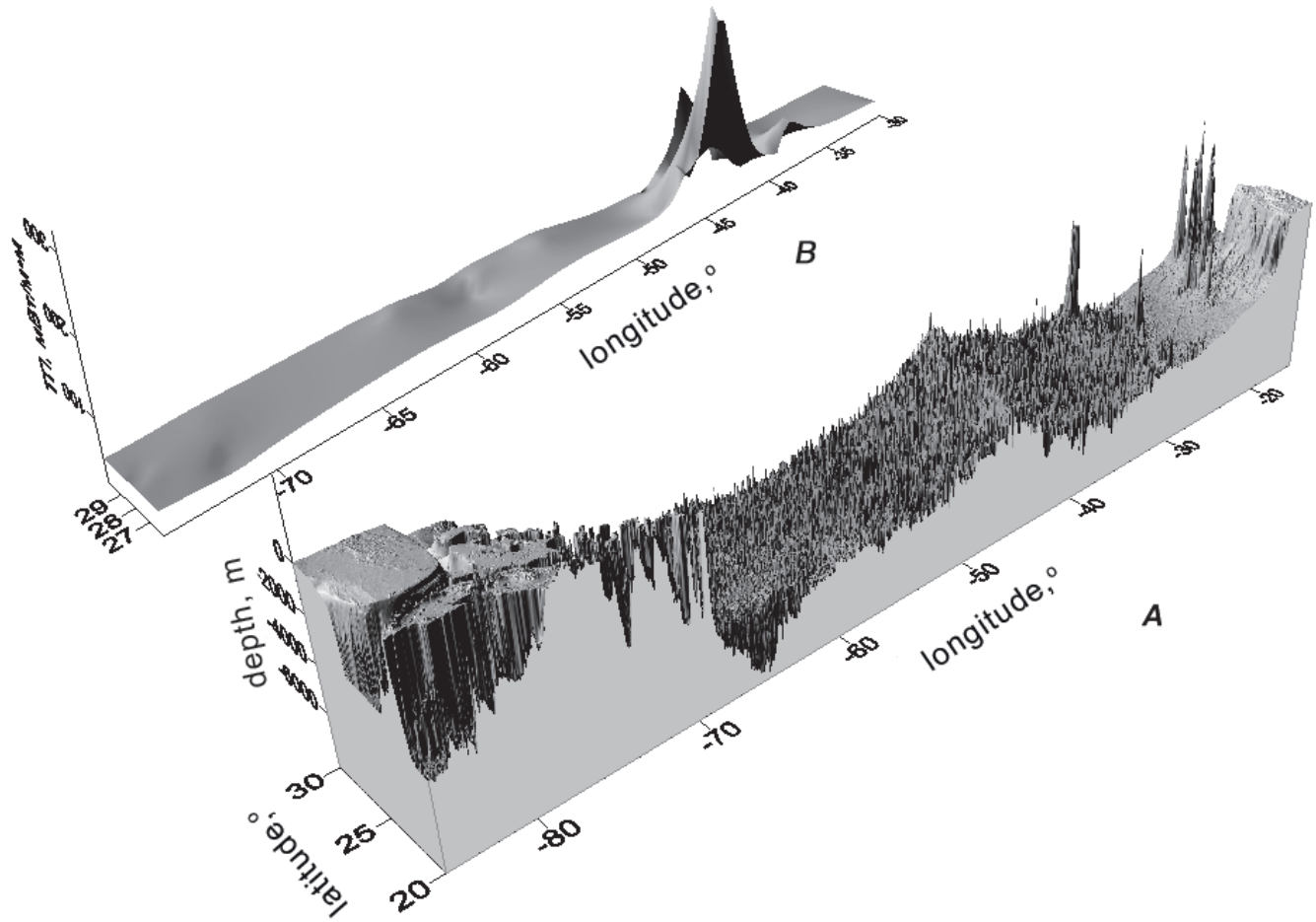

Fig. 6. Block diagrams of the bottom relief (A) and heat flow (B) along geotraverse No. 7 (Canaro-Bahamian)

as a complex of parallel dikes; the third seismic complex, due to the presence of dynamically expressed reflecting areas and inclined reflectors, corresponds to the lower parts gabbroids of the typical ophiolites section. On most temporary sections of the seismic reflection survey, the Moho section is highlighted, marking the transition from "layered" to "nonlayered" recording. On the seismic reflection profiles in the Canary-Bahamian geotraverse band, there are also areas where the wave fields have anomalous features: saturation with diffraction axes or reflecting the boundaries of a complex structure (inclined and "spike-shaped" reflectors).

Manifestations of asymmetry on the geotraverse were noted in the analysis of the "root dependence" of the relief on the slopes of the Mid-Atlantic Ridge (Mashchenkov et al., 1998), the gravitational free air anomalies (Gaynanov, 1980; Kuo, Forsyth, 1988) and heat flow (Podgornykh, Khutorskoy, 1999). However, a statistical comparison of the geothermal characteristics of the same morphological elements along the CanaryBahamian geotraverse revealed their heterogeneity. For example, a comparison of heat flow statistics in abyssal basins showed that in the Canary Basin in the geotraverse strip, heat flow is statistically significantly higher than in the southern part of the North American (Bahamian) basin. At the same time, a comparison of heat-flow distribution on the slopes of Mid-Atlantic Ridge did not reveal a significant difference from the east and west sides of the ridge axis.

The emergence of a new, much more representative database on heat flow (Hasterok et al., http://heatflow. org/data) made it possible to significantly increase the analyzed sample in the Canary-Bahamian geotraverse. If earlier in the geotraverse strip we analyzed 42 measurements, in the last base we included 70 measurements for the same coordinates.

Table 5 shows the results of statistical processing of heat flow samples in the western and eastern the geotraverse periphery. Calculations showed that, despite a slight excess of the average heat flow east of Mid-Atlantic Ridge, this difference is statistically insignificant, i.e. there is no reason to consider the existence of a geothermal asymmetry on this geotraverse. A possible interpretation of this result will be given below. 


\begin{tabular}{|l|c|c|}
\hline Canary-Bahamian geotraverse No. 7 \\
\hline west/east & west & east \\
\hline Average value of heat flow & 58 & 61 \\
\hline Standard deviation & 48 & 39 \\
\hline Number of measurements & 50 & 20 \\
\hline $\begin{array}{l}\text { Value of Cramer-Welch } \\
\text { criterion }\end{array}$ & \multicolumn{2}{|c|}{0,27} \\
\hline Confidence probability & $\begin{array}{l}<20 \% \text { (no significant } \\
\text { difference) }\end{array}$ \\
\hline
\end{tabular}

Table 5. Statistical characteristics for the values of the heat flow $\left(\mathrm{mW} / \mathrm{m}^{2}\right)$ according to geotraverse No. 7

Fig. 7 shows the relief of the bottom in the geotraverse area of $19^{\circ} \mathrm{N}$ (No. 8). This earth's crust block is almost unaffected by transform displacements and can be considered as a tectonotype of the symmetrical arrangement of the ocean floor morphological elements: slopes of Mid-Atlantic Ridge and adjacent abyssal basins.

However, a comparison of heat flow samples generated from measurements on different sides of the Mid-Atlantic Ridge axis showed a statistically significant difference - the eastern flank of the geotraverse has a higher average heat flow (Table 6).

\section{Pacific Ocean}

In the Pacific, only one geotraverse in the northern hemisphere satisfies the condition of sufficient geothermal study. This geotraverse is No. 9, crossing the EPR at $10^{\circ} \mathrm{N}$. More than 5000 heat flow measurements were obtained along this geotraverse by efforts of mainly American researchers (McKenzie, Sclater, 1969; Parsons, Sclater, 1977; Von Herzen, Uyeda, 1963). The overwhelming number of measurements lies in the range of $65-100 \mathrm{~mW} / \mathrm{m}^{2}$. Only about 20 points are characterized by hurricane values of $250-260 \mathrm{~mW} / \mathrm{m}^{2}$, gravitating towards the axis of the East Pacific Rise. Statistical analysis showed a slight but significant difference in heat flow of the East Pacific Rise flanks: the eastern flank has a higher average value than the western flank (Table 7).

\section{The discussion of the results}

A comparison of geothermal data for geotraverse flanks crossing all the MORs in the Worls oceans revealed a statistically significant asymmetry of heat flow that varies in direction in the southern and northern the Earth hemispheres: in the southern hemisphere, higher heat flow characterises the western flanks of geotraverses, and in the north - the eastern flanks. Of the nine geotraverses studied, only one of them (Canary-Bahamian) shows a statistically insignificant heat flow difference on the oppositt sides of Mid-Atlantic Ridge.

The explanation of this phenomenon requires not only the correction of the basic principles of the ocean bottom spreading paradigm, but also the more global, planetary causes of asymmetry in the fast and slowly spreading ridges. There are at least two possible causes that complicate the symmetrical divergence mechanism. They include differing age of tectonic plates blocks on opposite sides of the axis of the ridge and/ or the imposition of secondary processes on primary spreading, which proceed with the release or energy absorption. Among such processes, we can point to the expansion of the crust in the accretion zone and in adjacent abyssal basins, which is accompanied by the formation of listric faults, as well as the formation of shaded blocks shielding the deep heat flow. With these tectonic processes, the complex redistribution of convective flows in the oceanic lithosphere upper part,

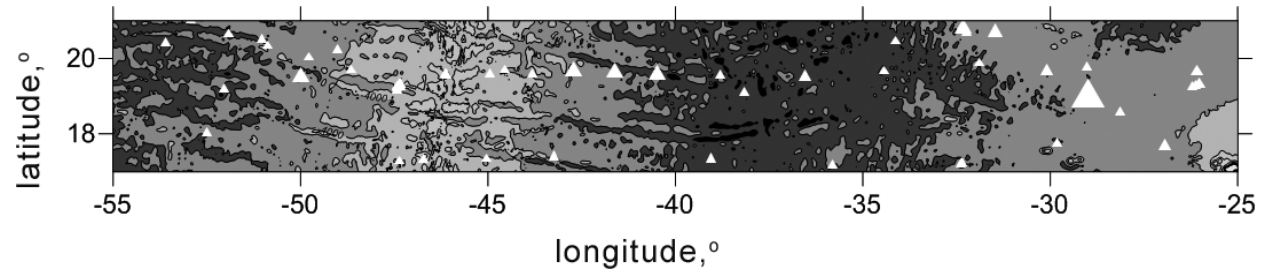

Fig. 7. Relief and position of measurement points of heat flow (triangles) along the geotraverse $19^{\circ} \mathrm{N}$ (the size of the triangles is proportional to the value of the heat flow)

\begin{tabular}{|l|c|c|}
\hline No. geotraverse & \multicolumn{2}{|c|}{$\begin{array}{c}\text { No. } 8 \\
19^{\circ} \text { n.1. }\end{array}$} \\
\hline west/east & west & east \\
\hline Average value of heat flow & 74 & 93 \\
\hline Standard deviation & 51 & 100 \\
\hline Number of measurements & 22 & 30 \\
\hline Value of Cramer-Welch criterion & \multicolumn{2}{|c|}{1,34} \\
\hline Confidence probability & \multicolumn{2}{|c|}{$82 \%$} \\
\hline
\end{tabular}

Table 6. Statistical characteristics for the values of the heat flow $\left(\mathrm{mW} / \mathrm{m}^{2}\right)$ according to the geotraverse of $19^{\circ} \mathrm{N}$. (No. 8)

\begin{tabular}{|l|c|c|}
\hline No. geotraverse & \multicolumn{2}{|c|}{$\begin{array}{c}\text { No. } 9 \\
10^{\circ} \text { n.l. }\end{array}$} \\
\hline west/east & west & east \\
\hline Average value of heat flow & 69 & 74 \\
\hline Standard deviation & 53 & 56 \\
\hline Number of measurements & 2829 & 3160 \\
\hline Value of Cramer-Welch criterion & \multicolumn{2}{|c|}{1,49} \\
\hline Confidence probability & \multicolumn{2}{|c|}{$87 \%$} \\
\hline
\end{tabular}

Table. 7. Statistical characteristics for the values of the heat flow $\left(\mathrm{mW} / \mathrm{m}^{2}\right)$ according to geotraverse $10^{\circ} \mathrm{N}$ in the Pacific Ocean (No. 9) 
which is fixed in the geothermal field by the presence of anomalously high and anomalously low (and even zero) heat flow values, is inextricably linked.

The existing methodology for the age of the second layer of the oceanic crust calculating according to geothermal data (eg, (Sorokhtin, 1974)) is based on the assumption of equal spreading speed on both sides of the oceanic ridges axis. Based on this, formula is derived that allows us to calculate the age of the bottom $(t)$ from the measurements of the heat flow $(q)$ :

$$
q=\lambda \cdot T_{a} / \sqrt{\pi a t},
$$

where $\lambda$ is the lithosphere thermal conductivity; $T_{a}$ is the temperature of the asthenosphere; $a$ is the thermal diffusivity, as well as the derivative of the other formula for estimating lithosphere thickness $\left(H_{L}\right)$ :

$$
H_{L}=\left(T_{s} / T_{a}\right) \sqrt{\pi a t},
$$

where $T_{s}$ is the solidus temperature of the mantle substance. The presence of geothermal asymmetry greatly complicates the application of these formulas and suggests another, more complex model for quantitative estimates of the oceanic lithosphere parameters. Previous studies of the oceanic crust age correlation with respect to magnetic anomalies and heat flow magnitude have not established a significant correlation (Budanov et al., 1997).

The idea of the geothermal asymmetry existence makes it possible to explain the reason for the correlation absence. These factors undoubtedly need to be taken into account when analyzing the geothermal field of the oceanic crust, but they do not explain the different "direction of asymmetry" in the northern and southern hemispheres. Above we mentioned the influence of the Coriolis force, which invariably manifests itself on a rotating Earth.

On any material point of the Earth $(m)$, due to its counterclockwise rotation with angular velocity $(\omega)$, the Coriolis force $\mathrm{F}_{\mathrm{k}}=2 m \cdot v \cdot \omega \cdot \sin \varphi$ will act, which in the southern hemisphere will shift the mass to the left relative to the radius (Fig. 8 ), and in the north, respectively, to the right. In the divergent zones, such a mass is magma rising from the asthenospheric mantle reservoir at a velocity $\mathrm{v}$, ensuring spreading of the ocean plates. However, we do not observe a connection between the rise of the magma rate $(v)$ nor the magnitude of the average heat flow, nor with the degree of asymmetry of its mean values on different sides of MOR. This follows from a comparative analysis of data on geotraverses in a rapidly spreading East Pacific Rise and in slow spreading Mid-Atlantic Ridge and West Indian Ridge. Under the action of the Coriolis force directed perpendicularly to the trajectory of the rise of the magma, the velocity vector becomes not orthogonal to the bottom surface, but shifted to the west. The mass $\mathrm{m}$ will move from point A to point B (Fig. 8).

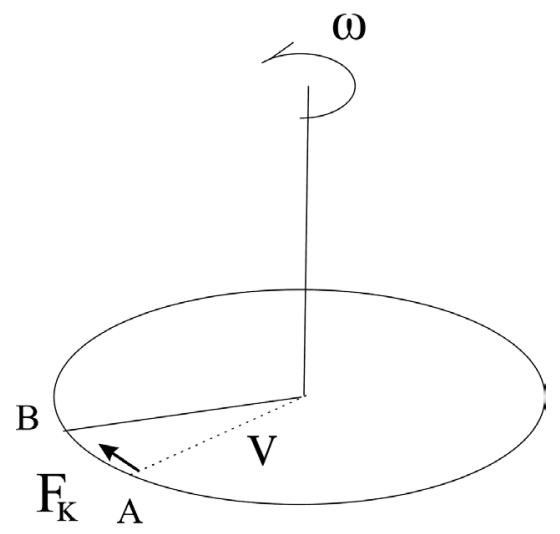

Fig. 8. The action of the Coriolis force (explanations in the text)

The amplitude of the displacement of the magmatic stream will be greater at high latitudes $(\varphi)$ than when approaching the equator. Under the action of the same force, the material point in the northern hemisphere will deviate to the east relative to the trajectory orthogonal to the surface of the planet.

Geotraverses No.No. 1-5 are located in the southern hemisphere, therefore the flow of rising magma invariably deviates to the west, which explains the observed asymmetry in the World Ocean.

For geotraverses No.No. 6-9 located in the northern hemisphere, the eastern flank of the geotraverse turns out to be more "warm", which can also be unambiguously associated with the influence of the Coriolis force. Here the exception is the Canary-Bahamian geotraverse (No. 7), in which the difference in average heat flows on the flanks was statistically insignificant. Apparently, the newest tectonic activity manifested in the Bahamian basin (Mashchenkov et al., 1997) increases the overall heat flow background on the western flank geotraverse flank.

Thus, we confirmed with the help of statistical analysis that in geotraverses of the southern hemisphere of the Earth, crossing the mid-oceanic ridges, their western flank has a higher mean arithmetic heat flow, and in the geotraverses of the northern hemisphere it is the eastern flank. The influence of the Coriolis force can be considered as the universal cause of this pattern, which, when the planet rotates, tilts the ascending stream of magma and other products of eruptions in divergent zones, respectively, to the west - in the southern hemisphere, and to the east - in the northern hemisphere.

\section{Acknowledgements}

The work was carried out with financial support of the state budget theme No. 0135-2015-0021 and the Program of Presidium of the Russian Academy of Sciences No. 49. 


\section{References}

Anderson, R.N., Langseth M.G., Hobart M.A. (1979). Geothermal convection through oceanic crust and sediments in the Indian Ocean. Science, 204, pp. 828-832. DOI: 10.1126/science.204.4395.828

Anderson, R.N., Langseth M.G., Sclater J.G. (1977). The mechanisms of heat transfer through the floor on the Indian Ocean. J. Geophys. Res., 82, pp. 3391-3409.

Budanov V.G., Ermakov B.V., Podgornykh L.V. (1997). Geophysical asymmetry of the wings of mid-Atlantic ridge (MAR): gravity, magnetic fields, heat flow. European Geophysical Society, Annales Geophysical, part I, Society Symposia, Solid Earth Geophysics \& Natural Hazards, Supplement I to Volume 15, SE27 Tectonic evolution and thermal structure at mid-ocean ridges, p.161.

Cannat M., Rommevaux-Jestin C., Sauter D., Deplus C., Mendel V. (1999). Formation of the axial relief at the very slow spreading Southwest Indian Ridge ( $49^{\circ}$ to $\left.69^{\circ} \mathrm{E}\right)$. J. Geophys. Res., 104, pp. 22825-22843.

Courtney, R.C., Recq M., (1986). Anomalous heat flow near the Crozet Plateau and mantle convection. Earth Planet. Sci. Lett., 79, pp. 373-384. DOI: https://doi.org/10.1016/0012-821X(86)90193-7

Gainanov A.G. (1980). Gravimetricheskie issledovaniya zemnoi kory okeanov [Gravimetric studies of the Earth's crust of the oceans]. Moscow: Moscow State University, 240 p. (In Russ.)

Glebovskii V.Yu., Kaminskii V.D., Osipov V.A. (1986). Struktura anomal'nogo magnitnogo polya ot sredinnogo khrebta do Angol'skogo shel'fa [Structure of an anomalous magnetic field from the middle ridge to the Angolan shelf]. Litosfera Angol'skoi kotloviny $i$ vostochnogo sklona Yuzhno-Atlanticheskogo khrebta [The lithosphere of the Angolan basin and the eastern slope of the South Atlantic Ridge]. Leningrad, pp. 70-80. (In Russ.)

Gmurman V.E. (2005). Teoriya veroyatnostei i matematicheskaya statistika [Theory of Probability and Mathematical Statistics]. Moscow: Vysshaya shkola Publ., pp. 327-349. (In Russ.)

Gorodnitskii A.M. (1985). Stroenie okeanicheskoi litosfery i formirovanie podvodnykh gor [The structure of the oceanic lithosphere and the formation of seamounts]. Moscow: Nauka Publ., 166 p. (In Russ.)

Hasterok D. (2010). Thermal Regime of the Continental and Oceanic

Lithosphere. Ph.D. Dissertation, University of Utah, $156 \mathrm{p}$.

Hasterok et al. http://heatflow.org/data

Hosford A. (2001). Crustal accretion and Evolution at slow and ultra-slow spreading mid-ocean ridges. Doct. Dissertation, Massachusetts Institute of Technology, 254 p. http://hdl.handle.net/1721.1/58441

Hyndman R.D., Langseth M.G., Von Herzen R.P. (1987). Deep Sea Drilling project geothermal measurements: a review. Rev. Geophys., 25(8), pp. 1563-1582. DOI: https://doi.org/10.1029/RG025i008p01563

Jessop, A.M., Hobart M.A., Sclater J.G. (1976). The world heat flow collection - 1975. Geothermal Series 5, Energy, Mines and Resources, Earth Physics Branch, Ottawa, Canada.

Khutorskoy M.D., Polyak B.G. (2017). Teplovoi potok v transformnykh razlomakh Severnoi Atlantiki i Yugo-Vostochnoi Patsifiki [Heat flow in the transform faults of the North Atlantic and South-Eastern Pacific]. Geotektonika $=$ Geotectonics, 2, pp. 55-66. (In Russ.)

Khutorskoy M.D., Teveleva E.A. (2016). Teplovoi potok v abissal'nykh kotlovinakh Patsifiki i Atlantiki [Heat flow in the abyssal basins of Pacific and Atlantic]. Monitoring. Nauka i tekhnologii = Monitoring. Science and technology, 4(29), pp. 20-27. (In Russ.)

Khutorskoy M.D., Teveleva E.A. (2018). O geotermicheskoi asimmetrii yugo-zapadnogo Indiiskogo khrebta [On the geothermal asymmetry of the southwestern Indian ridge]. Monitoring. Nauka i tekhnologii= Monitoring. Science and technology, 1. pp. 6-16. (In Russ.)

Khutorskoy M.D., Teveleva E.A., Podgornykh L.V. (2017). Geotermicheskaya asimmetriya transformnykh razlomov ekvatorial'noi chasti Atlanticheskogo okeana [Geothermal asymmetry of transform faults in the equatorial part of the Atlantic Ocean]. Doklady akademii nauk=Proc. of the Academy of Sciences, 475(3), pp. 325-328. (In Russ.)

Kuo B.-Y., Forsyth D.W. (1988). Gravity anomalies of the ridge transform system in the South Atlantic between 31 and $34,5^{\circ} \mathrm{S}$. Upvelling centers and variation in crustal thickness. Mar. Geophys. Res., 10, pp. 205232. DOI: https://doi.org/10.1007/BF00310065

Mashchenkov S.P., Pogrebitskii Yu.E. (1995). Simmetriya i asimmetriya SAKh po materialam kompleksnykh geofizicheskikh issledovanii na atlanticheskikh geotraversakh [Symmetry and asymmetry of the MAR on the basis of data from complex geophysical studies on Atlantic geotraverses]. Geologiya i mineral'nye resursy Mirovogo okeana [Geology and mineral resources of the World Ocean]. St. Petersburg: VNIIOkeanologiya Publ., pp. 64-79. (In Russ.)
Mashchenkov S.P., Pogrebitsky Yu.E., Astafurova E.G. et al. (1998). Glubinnoe stroenie i evolyutsiya litosfery Tsentral'noi Atlantiki (rezul'taty issledovanii na Kanaro-Bagamskom geotraverse) [Deep structure and evolution of the lithosphere of the Central Atlantic (research results on the Canary-Bahamian geotraverse)]. St. Petersburg: VNIIOkeanologiya Publ., 290 p. (In Russ.)

McKenzie D.P., Sclater J.G. (1969). Heat flow in the eastern Pacific and sea-floor spreading. Bulletin of Volcanology, 33, pp. 101-118.

Menard H.W. (1966). Fracture zones and offsets of the East-Pacific rise. J. Geophys. Res., 71(2), pp. 682-685. DOI: https://doi.org/10.1029/ JZ071i002p00682

Naryshkin G.D., Pogrebitsky Yu.E. (1986). Morfostruktura dna YugoVostochnoi Atlantiki [Morphostructure of the bottom of the South-East Atlantic]. Litosfera Angol'skoi kotloviny i vostochnogo sklona YuzhnoAtlanticheskogo khrebta [The lithosphere of the Angolan basin and the eastern slope of the South Atlantic Ridge], Leningrad, pp. 10-23. (In Russ.)

Parsons B., Sclater I.C., (1977). An analysis of the variation of ocean floor bathymetry and heat flow with age. J. Geophys. Res., 82(5), pp. 883-890.

Patriat P., Sauter D., Munschy M., Parson L. (1997). A survey of the Southwest Indian Ridge axis between Atlantis II Fracture zone and the Indian Ocean Triple Junction : Regional setting and large-scale segmentation. Mar. Geophys. Res., 19, pp. 457-480. DOI: https://doi. org/10.1023/A:1004312623534

Pogrebitsky Yu.E., Goryachev Yu.V., Osipov V.A., Trukhalev A.I. (1990). Stroenie okeanicheskoi litosfery po rezul'tatam issledovanii na Angolo-Brazil'skom geotraverze [The structure of the oceanic lithosphere from the results of studies on the Angola-Brazil geotraverse]. Sov.geologiya = Soviet Geology, 3, pp. 8-22. (In Russ.)

Podgornykh L.V., Khutorskoy M.D. (1997). Planetarnyi teplovoi potok [Planetary heat flow]. A map of scale 1: 30000000 and an explanatory note to it. Moscow-St. Petersburg, Orgservis LTD, 65 p. (In Russ.)

Podgornykh L.V., Khutorskoy M.D. (1998). Asimmetriya raspredeleniya teplovogo potoka vdol' Angolo-Brazil'skogo geotraversa (Yuzhnaya Atlantika) [Asymmetry of heat flow distribution along the Angola-Brazil geotraverse (South Atlantic)]. Doklady RAN=Proc.of the Russian Academy of Sciences, 355(4), pp. 212-215. (In Russ.)

Podgornykh L.V., Khutorskoy M.D. (1999). Geotermicheskaya asimmetriya sredinnykh khrebtov Mirovogo okeana [Geothermal asymmetry of the medial ridges of the World Ocean]. Geotektonika = Geotectonics, 3, pp. 21-42. (In Russ.)

Pollack, H.N., Hurter S.J., Johnston J.R. (1992). Global heat flow data set. World Data Center A for Solid Earth Geophysics. NOAA E/GCI, 325 Broadway, Boulder, CO 80303, USA.

Popova A.K., Smirnov Ya.B., Khutorskoy M.D. (1984). Geotermicheskoe pole transformnykh razlomov. Glubinnye razlomy okeanskogo dna [Geothermal field of transform faults. Deep faults in the ocean floor] Moscow: Nauka Publ., pp.78-87. (In Russ.)

Pushcharovsky Yu.M., Peive A.A., Raznitsin Yu.N., Bazilevskaya E.S. (1995). Razlomnye zony Tsentral'noi Atlantiki [Fault zones of the Central Atlantic]. Tr. GIN RAN [Proc. of the Geological Institute of the Russian Academy of Sciences], 495, Moscow: GEOS Publ., 163 p. (In Russ.)

Shreider A.A. (2001). Geomagnitnye issledovaniya Indiiskogo okeana [Geomagnetic studies of the Indian Ocean]. Moscow: Nauka Publ., 320 p. (In Russ.)

Sorokhtin O.G. (1974). Global'naya evolyutsiya Zemli [Global evolution of the Earth]. Moscow: Nauka Publ., 184 p. (In Russ.)

Von Herzen R.P., Uyeda S. (1963). Heat flow through the eastern Pacific ocean floor. J. Geophys. Res., 68(14), pp. 4219-4250. DOI: https:// doi.org/10.1029/JZ068i014p04219

\section{About the Authors}

Mikhail D. Khutorskoy - DSc (Geology and Mineralogy), Professor, Head of the Heat and Mass Transfer Laboratory

Geological Institute of the Russian Academy of Sciences

7 Pyzhevsky lane, Moscow, 119017, Russain Federation

E-mail: mkhutorskoy@ginras.ru 
Elena A. Teveleva-PhD (Physics and Mathematics), Senior Researcher, Laboratory of the Heat and Mass Transfer

Geological Institute of the Russian Academy of Sciences

7 Pyzhevsky lane, Moscow, 119017, Russain Federation
Manuscript received 1 April 2018; Accepted 2 June 2018; Published 30 June 2018 